Original Research Paper

\title{
Preliminary Study: Habitat Characteristics of Amorphophallus spp. to Support Cultivation Development in East Lombok
}

\author{
Janwar Wahyu ${ }^{1}$, Arben Virgota ${ }^{2 *}$, Sukiman ${ }^{1}$, Baiq Farista ${ }^{2}$, Suripto ${ }^{2}$ \\ ${ }^{1}$ Program Studi Biologi, Fakultas Matematika dan Ilmu Pengetahuan Alam, Universitas Mataram, \\ Indonesia \\ ${ }^{2}$ Program Studi Ilmu Lingkungan, Fakultas Matematika dan Ilmu Pengetahuan Alam, Universitas \\ Mataram, Indonesia
}

\author{
Article History \\ Received : October $20^{\text {th }}, 2021$ \\ Revised : October 29 2021 \\ Accepted : December $29^{\text {th }}, 2021$ \\ Published : January $05^{\text {th }}, 2022$ \\ *Corresponding Author: \\ Arben Virgota, \\ Program Studi Ilmu Lingkungan, \\ Fakultas MIPA, \\ Universitas Mataram \\ Email: arben@unram.ac.id
}

\begin{abstract}
One type of the Amorphophallus genus that has high economic value is Amorphophallus Muelleri, which is known as the local name Porang. Porang tubers are used to obtain glucomannan which is widely used in the drug industry. Currently, many porang tubers come from the forest and have not been widely cultivated. In Lombok island of, several species of Amorphophallus spp are found. Therefore, a preliminary study of the habitat information of Amorphophallus spp. in East Lombok is urgently needed, especially in the Kokok Tojang sub-watershed. This study aims to determine the habitat of Amorphophallus spp based on actual and potential existence data. The method used in this study is a purposive sampling method, namely by looking for actual and potential locations where Amorphophallus spp. In this study, two types of Amorphophallus were found, namely A. paeoniifollius and A muelleri. Habitat characteristics of Amorphophallus spp described by soil and microclimate parameters. Soil parameters include soil moisture (15-70\% and an average of 28.5\%); Soil temperature (24-29 oC), soil fertility (ideal) soil texture (clay clay, sandy loam, and dusty clay), conductivity $(0.07-0.52 \mathrm{mS} / \mathrm{cm})$. Microclimate parameters measured include temperature $(19.4-30.3 \mathrm{oC})$, humidity $(64.4 \%-81.4 \%)$, light intensity $(60.3-22526.8$ lux $)$.
\end{abstract}

Keywords: Amorphophallus spp., Kokok Tojang Sub Watershed, Distribution, Soil Parameters, Microclimate.

\section{Pendahuluan}

Amorphophallus spp. merupakan jenis tanaman herba yang termasuk ke dalam Famili Araceae dan dari kelas Monocotyledoneae. Salah satu ciri khas tanaman Amorphophallus spp. adalah mempunyai toleransi yang tinggi terhadap lingkungan yang ternaungi melalui mekanisme dormansi, sehingga tanaman ini tumbuh dengan baik di pekarangan maupun kawasan hutan (Hidayat dkk., 2013). Amorphophallus spp. dibudidayakan sebagai sumber produksi Glukomanan atau KGB yang dimanfaatkan pada berbagai bidang industri.

Flach dan Rumawas (1996) dalam Badan Litbang Pertanian (2015) di Indonesia terdapat 4 spesies Amorphophallus yang dominan dibudidayakan sebagai bahan pangan ataupun produsen glukomanan yaitu Amorphophallus konjac, Amorphophallus muelleri, Amorphophallus paeonifollius dan Amorphophallus variabilis. Porang (Amorphophallus spp.) belum banyak diketahui oleh masyarakat lokal sehingga tidak banyak dimanfaatkan. Beberapa jenis dikenal di pulau Lombok Amorphophalus diantaranya adalah iles-iles (A. muelleri) dan suweg (A. paeniifollius). Kedua jenis ini banyak ditemukan tumbuh di bawah naungan pohon atau di sela-sela tanaman lain di kebun campuran ataupun di hutan (Yasin, dkk., 2021). Meskipun dapat tumbuh dengan baik di alam liar, pertumbuhan tanaman tersebut membutuhkan kondisi tertentu untuk dapat tumbuh secara optimal, beberapa faktor di antaranya ketinggian 
lokasi, tekstur tanah, intensitas naungan dan kelembaban tanah (Litbang Pertanian, 2015).

Penelitian yang telah dilakukan sebelumnya telah membuktikan bahwa faktor naungan sangat mendukung pertumbuhan porang (Amorphophallus spp.). Sementara itu, informasi yang terkait dengan parameter lingkungan yang mendukung pertumbuhan porang di pulau Lombok, khususnya di Lombok Timur masih sangat kurang. Oleh karena itu perlu dilakukan penelitian dengan tujuan untuk mengetahui Kesesuaian habitat Amorphophallus spp. di Sub DAS Kokok Tojang.

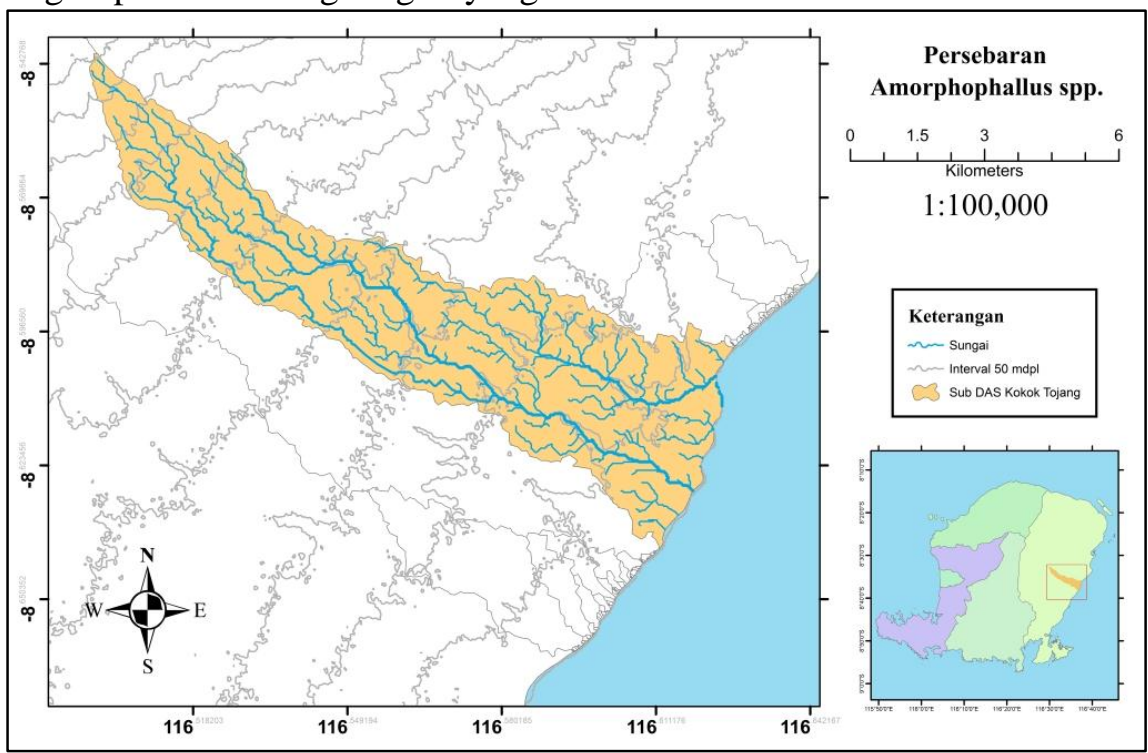

Gambar 1. Peta lokasi penelitian

\section{Bahan dan Metode}

\section{Waktu dan lokasi penelitian}

Penelitian ini akan dilaksanakan pada bulan April hingga bulan Juli 2021 bertempat di Sub DAS Kokok Tojang, Kabupaten Lombok Timur. Sub DAS Kokok Tojang terletak pada ketinggian $0-500 \mathrm{mdpl}$, melintasi Kecamatan Aikmel, Wanasaba dan Labuhan Haji.

\section{Prosedur penelitian}

1. Desain lokasi penelitian

Untuk membantu dalam melakukan survei lokasi, hal pertama yang dilakukan adalah membagi wilayah Sub DAS Kokok Tojang (Gambar 2), menjadi tujuh bagian (blok) berdasarkan ketinggian. Setiap blok dikonversi menjadi titik koordinat yang dapat dibaca dengan alat Global Positioning System (GPS) untuk mengarahkan eksplorasi di lapangan.

Penelitian ini dilakukan dengan survei lokasi guna mengetahui lokasi aktual maupun potensial pertumbuhan porang di wilayah Sub
DAS Kokok Tojang menggunakan metode sampling snowball.

\section{Penelitian pendahuluan}

Sampling snowball dilakukan dengan metode wawancara secara semi-terstruktur, yakni dengan menggunakan kuesioner dan wawancara secara langsung. Sampling Snowball dimaksudkan untuk mendapatkan informasi mengenai lokasi Amorphophallus spp. yang pernah ditemukan atau terlihat oleh masyarakat sekitar. Metode ini digunakan karena pada saat penelitian ini berlangsung telah memasuki awal musim kemarau sehingga banyak populasi Amorphophallus spp. yang telah memasuki fase dorman. Resposnden yang dipilih adalah masyarakat lokal yang memiliki banyak aktivitas di sekitar lokasi penelitian, diantaranya adalah pencari kayu, penggembala, pencari rumput atau siapa saja yang direkomendasikan oleh responden awal. 


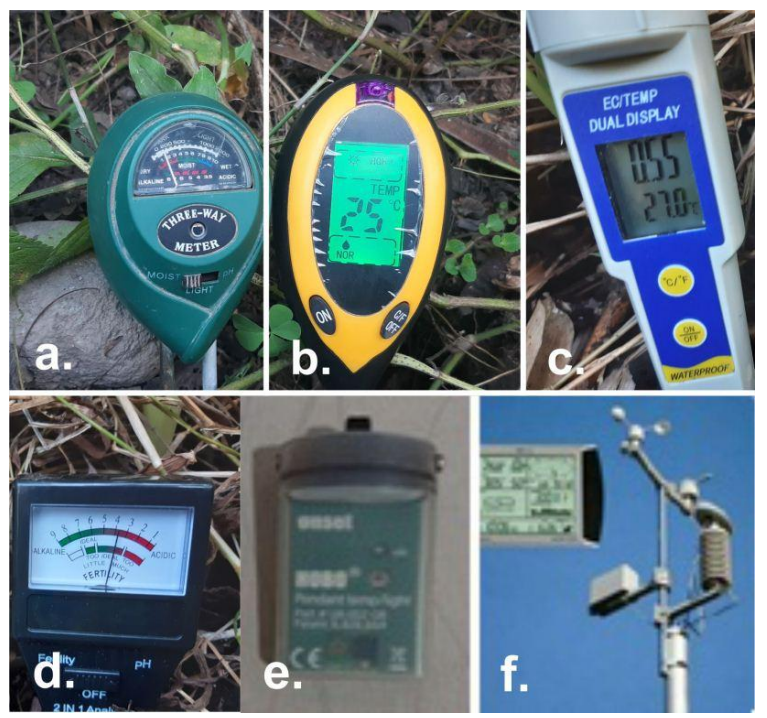

Gambar 2. Alat-alat ukur. a. Soil tester1; b. Soil tester2; c. EC Soil tester; d. Fertility tester; e. Data Logger; f. Weather Station.

\section{Pengumpulan data}

Pengukuran data ekologi dilakukan dengan menggunakan metode Purposive sampling, yaitu dengan mencari lokasi aktual dan potensial di mana Amorphophallus spp. ditemukan. Dan selanjutnya dilakukan pengukuran mikroklimat menggunakan Data Logger, khusus untuk parameter cahaya dan suhu, sedangkan kelembaban diukur mengguanakan alat weather station. Pengukuran ini dilakukan selama 2 bulan.

Pengukuran parameter tanah seperti suhu, kelembaban tanah, $\mathrm{pH}$ diukur menggunakan Soil Tester. Tingkat kesuburan tanah diukur menggunakan Fertility Tester dan KTK menggunakan pendekatan nilai konduktivitas tanah dengan bantuan alat EC Soil Tester.

Penilaian tekstur tanah dilakukan dengan menggunakan segitiga tekstur tanah yakni dengan menghitung perbandingan jumlah liat, debu dan pasir. Tahapan pengukuran fraksi tanah dilakukan menggunakan saringan, botol, dan air. Sampel tanah yang dikumpulkan disaring terlebih dahulu. Tanah yang telah disaring dimasukkan kedalam botol kaca yang telah berisi air, kemudian diaduk hingga homogen dan didiamkan selam kurang lebih 24 jam. Setelah diendapkan akan diperoleh perbandingan fraksi pasir, debu dan liat, dan selanjutnya dianalisis menggunakan segitiga tekstur tanah (Friyandito, 2021).

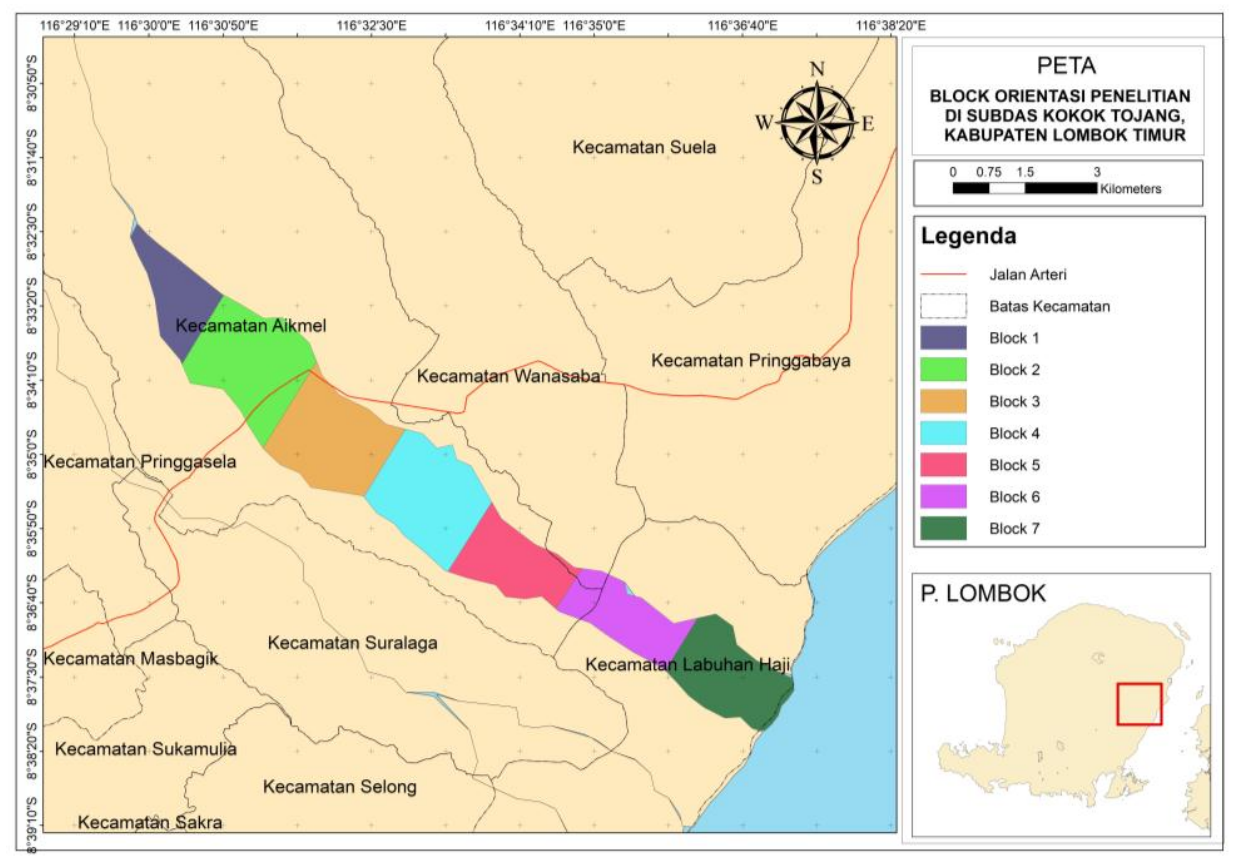

Gambar 3. Blok peta orientasi penelitan

Analisis data
Peta persebaran Amorphophallus spp. di wilayah Sub DAS Kokok Tojang, Lombok Timur 
dibuat dengan analisis sistem informasi geografis (SIG). Perangkat lunak yang digunakan dalam analisis SIG ini adalah ArcGis 10.8. Tahapan pertama penyusunan peta persebaran Amorphophallus spp. adalah membuat peta dasar wilayah Sub DAS Kokok Tojang menggunakan DEM (Digital Elevation Model) dengan resolusi 0.27 arcsecond $\left(8.1 \mathrm{~m}^{2}\right.$ ) dan Batnas (Batimetri Nasional) yang didapatkkan dari situs Indonesia Geoportal. Tahap kedua, dilakukan survei lokasi ditemukannya Amorphophallus spp. dan di rekam posisi koordinatnya menggunakan GPS. Tahap selanjutnya, gabungan peta dasar dan koordinat lokasi diproyeksikan dengan WGS UTM 50S menyesuaikan dengan posisi wilayah Pulau Lombok.

\section{Hasil dan Pembahasan}

\section{Persebaran potensial Amorphophallus spp.}

Beberapa jenis Amorphophallus spp yang dikenal di pulau Lombok Amorphophalus diantaranya adalah iles-iles (A. muelleri) dan suweg (A. paeniifollius). Kedua jenis ini banyak ditemukan tumbuh di bawah naungan pohon atau di sela-sela tanaman lain di kebun campuran ataupun di hutan (Yasin, dkk., 2021). A. muelleri Blume (A. oncophyllus Prane) ialah spesies Amorphophallus yang dikenal sebagai porang (Srzednicki dan Boromphichaicarkul, 2020).

Litbang Pertanian (2015) menjelaskan bahwa porang umumnya terdapat di lahan kering pada ketinggian hingga $800 \mathrm{~m}$ di atas permukaan laut, namun yang bagus adalah daerah dengan tinggi $100-600 \mathrm{mdpl}$. Untuk pertumbuhannya memerlukan suhu $25-35{ }^{\circ} \mathrm{C}$, dan curah hujan 1.000-1.500 $\mathrm{mm} /$ tahun dan tersebar rata sepanjang tahun.

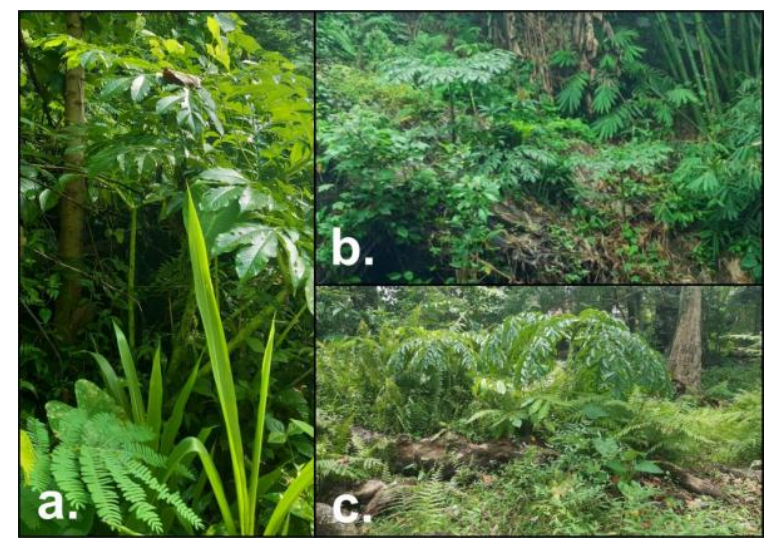

Gambar 4. a, b, dan c adalah A. paenifollius (Dennst.) banyak ditemukan di wilayah Sub DAS Kokok Tojang

Persebaran titik pertumbuhan potensial tertinggi $438 \mathrm{mdpl}$ dan titik terendah pada $24 \mathrm{~m}$ dpl di Sub DAS Kokok Tojang. Gambar 5. diketahui persebaran Amorphophallus spp. di Sub DAS Kokok Tojang dapat ditemukan pada blok 1, 2, 3, 4 dan 7. Lokasi tersebut memiliki potensi sebagai lokasi pertumbuhan Suweg (Amorphophallus paeoniifollius) dan Iles-iles (Amorphophallus muelleri).

Tabel 1. Persebaran Amorphophallus di wilayah Sub DAS Kokok Tojang.

\begin{tabular}{clcl}
\hline Blok & \multicolumn{2}{l}{ Lokasi (mdpl) } & Spesies \\
\hline \multirow{3}{*}{1} & B1T1 & 359 & A. paeoniifollius (Dennst.) \\
\cline { 2 - 4 } & B1T2 & 410 & A. paeoniifollius (Dennst.) \\
\cline { 2 - 4 } & B1T3 & 438 & A. paeoniifollius (Dennst.) \\
\hline \multirow{3}{*}{2} & B2T1 & 278 & A. paeoniifollius (Dennst.) \\
\cline { 2 - 4 } & B2T2 & 308 & A. paeoniifollius (Dennst.) \\
\cline { 2 - 4 } & B2T3 & \multirow{2}{*}{305} & A. paeoniifollius (Dennst.) \\
\cline { 2 - 4 } & & A. muelleri Blume. \\
\hline 3 & B3T1 & 202 & A. paeoniifollius (Dennst.) \\
\hline 4 & B4T1 & 173 & A. paeoniifollius (Dennst.) \\
\hline \multirow{2}{*}{5} & B7T1 & 24 & A. paeoniifollius (Dennst.) \\
\cline { 2 - 4 } & B7T2 & 41 & A. paeoniifollius (Dennst.) \\
\hline
\end{tabular}




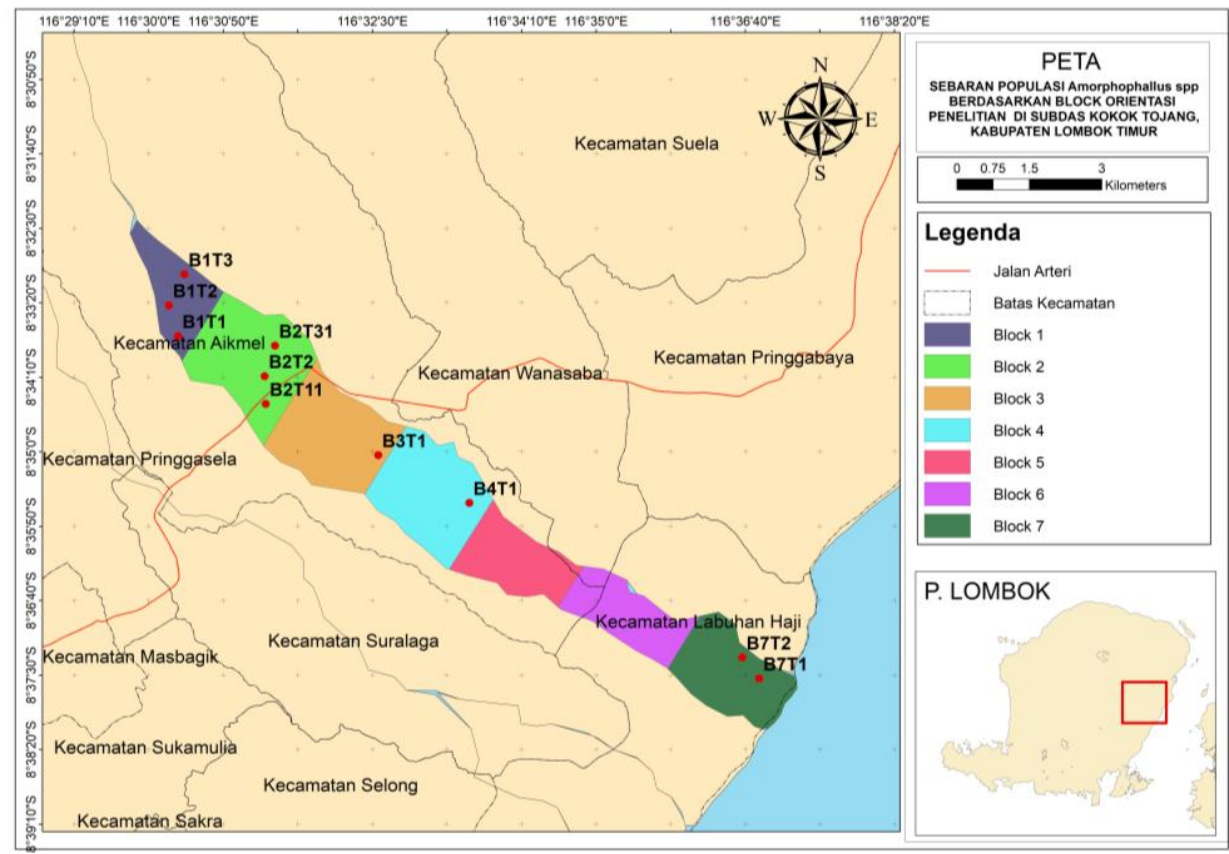

Gambar 5. Peta persebaran Amorphophallus spp. di Sub DAS Kokok Tojang

\section{Karakteristik Habitat}

\section{Parameter tanah}

Pengukuran faktor tanah meliputi kelembaban, suhu, $\mathrm{pH}$ tanah, serta fertilitas dan konduktivitas tanah.

1. Kelembaban tanah.

Amorphophallus spp. membutuhkan daerah ternaung untuk keberlangsungan hidupnya, hal ini menunjukkan kelembaban memiliki peran penting dalam pertumbuhannya. Kelembaban tanah bergantung pada tingkat penyerapan tanah terhadap jumlah air di lingkungan sehingga mengisi pori - pori di dalam tanah. Berdasarkan hasil pengukuran pada tabel 1 diketahui rata-rata kelembaban tanah di lokasi pertumbuhan Amorphophallus spp. berkisar antara $15-70 \%$ atau rata-rata $28.5 \%$. Nilai tersebut menunjukkan kondisi di lokasi yang relatif kering. Kelembaban tanah tidak berpengaruh terhadap perkecambahan (sprouting) ubi, namun berpengaruh terhadap pertumbuhan dan perkembangan tunas. Apabila kelembaban tanah sepanjang periode pertumbuhan tercukupi, tanaman porang akan menghasilkan ubi yang besar. Kondisi yang hangat dan lembab diperlukan untuk pertumbuhan daun dan kondisi kering diperlukan untuk perkembangan umbi (Litbang Pertanian, 2015). Oleh sebab itu umbi porang akan berkembang optimum pada wilayah dengan curah hujan 1000-1500 mm/tahun.

2. Suhu tanah

Suhu dan ketinggian mempunyai pengaruh yang tinggi terhadap kelembaban udara dan tanah. Distribusi suhu di dalam tanah bergantung pada beberapa faktor, diantaranya konduktivitas panas, kapasitas panas dan warna tanah. Karena penjalaran panas ke dalam tanah memerlukan waktu, maka suhu tanah pada setiap kedalaman yang lebih dalam mengalami keterlambatan (Tjasyono, 1999). Dari hasil pengukuran diketahui bahwa rata-rata suhu tanah berkisar antara $24-29{ }^{\circ} \mathrm{C}$ atau rata-rata $26.1{ }^{\circ} \mathrm{C}( \pm 15 \mathrm{~cm}$ di bawah permukaan tanah). Secara umum, fluktuasi suhu tanah sangat dipengaruhi oleh fluktuasi suhu udara di permukaan yang sedang terjadi saat itu. Pengaruh perubahan suhu udara terhadap suhu tanah terjadi pada berbagai kedalaman berbeda, baik pada siang hari maupun malam hari (Karyati dan Ardianto, 2016).

3. Kesuburan tanah

Bahan organik diukur dengan pendekatan kualitatif menggunakan Fertility Tester, 
memiliki tiga interval yang menunjukkan tingkat kesuburan yaitu sangat sedikit (1), ideal (2), dan sangat ideal (3). Tingkat kesuburan sendiri menunjukkan jumlah bahan organik yang terdapat pada suatu lokasi. Menurut Wijanarko, dkk, 2012., penambahan bahan organik dalam tanah akan meningkatkan konsentrasi $\mathrm{N}$ dan $\mathrm{C}$ sebagai salah satu indikator kesuburan tanah.
Berdasarkan hasil pengukuran, semua lokasi potensial menunjukkan tingkat kesuburan yang ideal, dimana tingkat kesuburan ideal dibagi menjadi 3 skala $(1=$ cukup ideal, $2=$ ideal dan 3 $=$ sangat ideal). Berdasarkan tabel 2 rata-rata tingkat kesuburan ideal terletak pada interval ke2 dengan $\mathrm{pH}$ rata-rata 7 (netral).

Tabel 2. Hasil Pengukuran Parameter Tanah Lokasi Pertumbuhan Amorphophallus spp. di Sub DAS Kokok Tojang.

\begin{tabular}{|c|c|c|c|c|c|c|c|}
\hline \multirow{2}{*}{ Blok } & \multirow{2}{*}{ Lokasi } & \multirow{2}{*}{ Nama daerah } & \multirow{2}{*}{ Fertilitas } & \multirow{2}{*}{$\begin{array}{c}\text { Konduktivitas } \\
(\mathbf{m S} / \mathbf{c m})\end{array}$} & \multicolumn{3}{|c|}{ Parameter tanah } \\
\hline & & & & & RH \% & $\mathrm{T}^{\circ} \mathrm{C}$ & pH \\
\hline \multirow{4}{*}{1} & B1T1 & Loang gali & 3 & 0.25 & 20 & 25 & 7 \\
\hline & B1T2 & Aik nyambuk & 1 & 0.07 & 15 & 25 & 7 \\
\hline & B1T3 & Otak aik & 2 & 0.29 & 20 & 24 & 7 \\
\hline & B2T1 & Nyiur baya & 2 & 0.39 & 20 & 26 & 7 \\
\hline \multirow[t]{2}{*}{2} & B2T2 & Timba manggong & 1 & 0.30 & 60 & 26 & 7 \\
\hline & B2T3 & Timba bokor & 2 & 0.20 & 30 & 25 & 7 \\
\hline 3 & B3T1 & Kalijaga & 1 & 0.16 & 20 & 25 & 7 \\
\hline 4 & B4T1 & Kebon idik & 1 & 0.07 & 15 & 28 & 7 \\
\hline \multirow{2}{*}{7} & B7T1 & Rumpang & 1 & 0.52 & 70 & 28 & 7 \\
\hline & B7T2 & Bangsal & 1 & 0.08 & 15 & 29 & 7 \\
\hline \multicolumn{3}{|c|}{ Rata-rata } & 2 & 0.23 & 28.5 & 26.1 & 7 \\
\hline
\end{tabular}

4. Konduktivitas tanah

Barbarosa dan Overstreet (2011)., menyatakan bahwa elektrikal konduktivitas tanah berpasir cenderung lebih rendah daripada tanah lempung, oleh sebab itu ukuran partikel dan tekstur tanah mempengaruhi tingkat konduktivitas tanah. Pada wilayah Sub DAS Kokok Tojang diketahui terdapat tiga tekstur tanah yakni Lempung berliat, lempung berpasir, dan lempung berdebu dengan konduktivitas ratarata $0,23 \mathrm{mS} / \mathrm{cm}$. Tabel 1 menunjukkan konduktivitas tanah terendah pada lokasi B4T1 yakni $0.07 \mathrm{mS} / \mathrm{cm}$ dan konduktivitas tertinggi terdapat pada lokasi B7T1 yakni $0.52 \mathrm{mS} / \mathrm{cm}$. Hal disebabkan oleh lokasinya yang dekat daerah pantai dan aliran sungai sehingga garam mineral yang terbawa dari hulu dan pelapukan mineral batuan terakumulasi pada wilayah yang dekat daerah pantai. Diketahui garam berasal dari pelapukan mineral dan batuan (USDA NRCS, 2021).

5. Tekstur tanah

Tekstur tanah adalah keadaan tingkat kehalusan tanah yang terjadi karena terdapatnya perbedaan komposisi kandungan fraksi kandungan tanah pasir, debu dan liat. Tekstur tanah seperti Liat dan bahan organik memegang peran sangat penting dalam menahan air tanah serta ketersediaan hara bagi tanaman. Partikel yang halus juga berperan sebagai agen perekat partikel tanah yang lebih kasar untuk membentuk agregat atau struktur tanah. Sementara itu, partikel tanah yang lebih besar berperan sebagai penyusun kerangka tubuh tanah, mempertahankan permeabilitas tanah, serta meningkatkan aerasi tanah. Berdasarkan hasil pengukuran komposisi tanah yaitu fraksi pasir, debu, dan liat dengan menggunakan segitiga tekstur tanah pada masing-masing lokasi diketahui bahwa terdapat 3 klasifikasi teksur tanah yang memiliki potensi dalam mendukung pertumbuhan Amorphophallus spp. di Sub DAS Kokok Tojang yaitu lempung berliat, lempung berpasir dan lempung berdebu. Tekstur tanah lempung berliat diketahui terdapat pada lokasi B1T1 dan lempung berpasir, pada lokasi B1T2, B1T3, B2T3 B4T1 dan B7T1 sementara lempung berdebu, pada lokasi B2T1,B2T2, B3T1 dan B7T2. 
Tabel 3. Hasil Pengukuran Parameter Mikroklimat Lokasi Pertumbuhan Amorphophallus spp. di Sub DAS Kokok Tojang

\begin{tabular}{ccccccc}
\hline \multirow{2}{*}{ Lokasi } & \multicolumn{2}{c}{ Suhu udara $\left({ }^{\circ} \mathbf{C}\right)$} & \multicolumn{2}{c}{ Kelembaban udara (\%) } & \multicolumn{2}{c}{ Intensitas cahaya (lux) } \\
\cline { 2 - 7 } & Interval & Rata-rata & Interval & Rata-rata & Interval & Rata-rata \\
\hline Blok 1 & $21.1-28$ & 23.7 & $61-82$ & 75.2 & $21.55-12055.6$ & 4218,4 \\
Blok 2 & $19.2-32.1$ & 24.2 & $59-84$ & 79.2 & $64.6-27555.7$ & 5896.7 \\
Blok 3 & $18.7-27.1$ & 23.2 & $63-82$ & 73.7 & $96.9-8266.7$ & 2595.0 \\
Blok 4 & $20.5-33.2$ & 24.1 & $70-81$ & 73.0 & $32.3-22044.6$ & 4566.6 \\
Blok 7 & $17.6-30.9$ & 24.4 & $69-78$ & 72.2 & $86.1-42711.4$ & 7501.3 \\
\hline Rataan & $19.4-30.3$ & 23.9 & $64.4-81.4$ & 74.7 & $60.3-22526.8$ & 5139.9 \\
\hline
\end{tabular}

\section{Parameter Mikroklimat}

Pengukuran iklim diukur dengan interval waktu 2 bulan yakni dari bulan juni hingga bulan juli 2021. Faktor iklim tersebut diantaranya

\section{Intensitas cahaya}

Suhu udara meningkat pada siang hari sejalan dengan bertambahnya intensitas matahari, dan menurun sedikit demi sedikit sampai jam 6 sore hingga matahari terbit lagi. Sedangkan pada malam hari sekitar pukul 18:00 hingga 05:00, tajuk pohon di dalam hutan juga dapat berfungsi untuk mempertahankan kondisi suhu udara minimum, sehingga fluktuasi suhu udara tidak terlihat jelas seperti pada saat siang hari (Karyati, 2019). Berdasarkan hasil pengukuran di lapangan pada tabel 3, dalam kondisi ternaung rata-rata peningkatan intensitas di pagi hari adalah 60.3 lux dan mengalami intensitas tertinggi pada siang hari yaitu 22526.8 lux, dengan rata-rata 5139.9 lux pada musim kemarau.

\section{Suhu udara}

Suhu mengalami peningkatan dikarenakan adanya radiasi sinar matahari. Tanaman umumnya memiliki suhu optimum untuk dapat tumbuh dengan baik. Berdasarkan hasil pengukuran pada pada tabel 3, diketahui bahwa suhu udara rata-rata di lokasi pertumbuhan porang di musim kemarau adalah $23.9^{\circ} \mathrm{C}$, yang mana Amorphophallus spp sedang mengalami siklus dormansi. Menurut Dwiyono dan Djauhari (2019), suhu optimum spesies Amor-phophallus berbeda-beda yaitu berkisar antara $20-35^{\circ} \mathrm{C}$.

\section{Kelembaban udara}

Menurut Widiningsih (1985) dalam Noorhadi (2003), kelembaban dan suhu udara merupakan komponen iklim mikro yang sangat mempengaruhi pertumbuhan tanaman dan masing-masing berkaitan mewujudkan keadaan lingkungan optimal bagi tanaman. Siklus dormansi Amorphophallus spp. terjadi pada musim panas. Hal ini menunjukkan suhu dan kelembaban memberikan stimulasi dalam pergantian siklus Amorphophallus spp. Kelembaban udara merupakan faktor yang dapat menstimulasi curah hujan. Wilayah tropis umumnya mengalami kelembaban tertinggi pada musim hujan dan terendah pada musim kemarau. Berdasarkan hasil pengukuran di wilayah Sub DAS Kokok Tojang rata-rata kelembaban udara cukup tinggi yaitu $74,7 \%$ dengan kelembaban minimum $59 \%$ dan maksimum $84 \%$ pada musim panas.

\section{Kesimpulan}

Karakteristik habitat ditemukannya Amorphophallus spp dikelompokkan berdasarkan parameter tanah dan parameter mikroklimat. Parameter tanah meliputi kelembaban tanah (15-70\% dan rata-rata $28.5 \%$ ); Suhu tanah $\left(24-29^{\circ} \mathrm{C}\right)$, kesuburan tanah (ideal ) tekstur tanah (Lempung berliat, lempung berpasir, dan lempung berdebu), konduktivita $(0.07-0.52 \mathrm{mS} / \mathrm{cm})$. Parameter Mikroklimat yang diukur meliputi suhu $\left(19.4-30.3^{\circ} \mathrm{C}\right)$, Kelembaban $(64.4 \%-81.4 \%)$, intensitas cahaya (60.3-22526.8 lux).

\section{Ucapan terima kasih}

Terima kasih disampaikan kepada Lembaga Penelitian dan Pengabdian kepada Masyarakat Universitas Mataram yang mendanai penelitian ini melalui Program PNBP. Terimakasih juga disampaikan kepada mahasiswa yang membantu dalam pengumpulan data selama penelitian. 


\section{Referensi}

Barbosa, R N. \& Overstreet, C., (2011). What Is Soil Electrical Conductivity, LSUAgCenter, Publication No. 318. https://www.lsuagcenter.com/ (Diakses pada 24 Oktober 2021)

Dwiyono, K., and Djauhari, M.A., (2019), Indonesian Konjac: its benefits in industry and food security, Universitas Nasional, Jakarta.

Friyandito, nd., (2021). Mengukur Persentase Tekstur Tanah (Pasir, Debu, Liat) Dan Interpretasi Hasil Pengukurannya. https://bestplanter indonesia.com (Diakses pada 14 April 2021)

Hidayat, R., Dewanti, D., \& Hartojo (2013). Tanaman Porang; karakter, manfaat dan budidaya, Graha Ilmu, Yogyakarta. ISBN: 978-602-262-119-5

Karyati \& Ardianto, S., (2016). Dinamika Suhu Tanah pada Kedalaman Berbeda di Hutan Pendidikan Fakultas Kehutanan Universitas Mulawarman, Jurnal Riset Kaltim, 4(1): 1-12.

Karyati (2019). Mikroklimatologi Hutan, Samarinda: Mulawarwan University Press, $\mathrm{p}: 23-24$.

Noorhadi, Sudadi (2003). Kajian pemberian air dan mulsa terhadap iklim mikro pada tanaman cabai di tanah entisol. J ilmu tanah dan lingkungan, 4 (1): 41-49.

Pusat Penelitian dan Pengembangan (2015), Tanaman Porang: pengenalan, budidaya dan pemanfaatannya, LitBang: Bogor. ISBN: 978-979-1159-64-7.

Srzednicki, G., and Boromphichaicarkul, C., (2020), Konjac Glukomannan; Production, Processing and Functional Applicaions, CRC Press, New York

Tjasyono, B. (1999). Klimatologi Umum. ITB. Bandung.
USDA NRCS, nd, (2021). Soil Electrical Conductivity - Soil Quality Kit. https://www.nrcs. usda.gov (Diakses pada 29 Oktober 2021)

Yasin, I., Suwardji, Kustana, Bustan \& Fahrudin, (2021). Menggali potensi Porang sebagai tanaman budidaya, di lahan hutan kemasyarakatan di Pulau Lombok, Prosiding SAINTEK, Vol 3 Januari 2021. https://jurnal.lppm.unram.ac.id/index.php/ prosidingsaintek/article/view/247 (Diakses pada 24 Oktober 2021). 